\title{
ЗНАЧЕННЯ ПРОЦЕСІВ ПРОТЕОЛІЗУ І АНТИПРОТЕАЗНОГО ПОТЕНЦІАЛУ В ЛЕГЕНЯХ У РАННІЙ ПЕРІОД РОЗВИТКУ ВИРАЗКОВОЇ ХВОРОБИ ШЛУНКА НА ТЛІ ЕКСПЕРИМЕНТАЛЬНОÏ ПНЕВМОНIÏ
}

Львівський національний медичний університет імені Данила Галицького

РЕЗЮМЕ. У роботі встановлено, що на 4 добу розвитку експериментальної пневмонії (ЕП) і виразкової хвороби шлунка (ВХШ) відбувається зростання рівнів азоколагену, азоказеїну, азоальбуміну та зниження вмісту альфа-2 макроглобулінів і альфа -1 - інгібітора протеаз в легенях. Пізніше, на 8 добу формування ЕП і ВХШ, спостерігалося подальше підвищення показників протеолізу на тлі суттєвого зниження маркерів антипротеазного потенціалу в легенях.

КЛЮчОВІ СЛОВА: азоказеїн, азоколаген, азоальбумін, інгібітори протеаз.

Вступ. Пневмонія - гостре інфекційне захворювання переважно бактеріальної етіології, яке характеризується вогнищевим ураженням респіраторних відділів легень та обов'язковою наявністю внутрішньоальвеолярної ексудації (МО3 України, 2007).

Незважаючи на великі досягнення в галузі діагностики та лікування захворювань органів дихання, ця патологія на початку XXI ст. продовжує зростати [1]. На сьогодні пневмонія належить до актуальних питань пульмонології, складає 3040 \% усіх захворювань легень та посідає 4 місце серед причин смертності $[2,3]$. На жаль, смертність від неї в Україні доволі висока і впродовж багатьох років не знижується. Збільшується кількість пацієнтів із тяжким перебігом захворювання, а коректний діагноз пневмонії встановлюють лише в кожного третього хворого [5].

В даний час активно проводяться експериментальні і клінічні дослідження захворювань у паці$\epsilon$ нтів з поєднаною патологією (синдром взаємного обтяження) [6, 7]. Крім ураження легень пневмонія призводить до значних позалегеневих ефектів, супутніх захворювань, які ускладнюють ї̈ перебіг.

Як патофізіологічну модель для взаємного обтяження патології ми обрали пневмонію і виразкову хворобу шлунка. Відомо, що в механізмах формування пневмонії важливу роль відграють імунна система, перекисне окиснення ліпідів і антиоксидантний захист, оксид азоту, біологічні активні речовини [4].

Виявлено, що продукти ПОЛ значно знижують активність основного інгібітора протеаз $-a_{1}-$ антитрипсину, а активація ПОЛ і висока активність протеолізу створюють сприятливі умови для розвитку пневмонії [4] Інтенсивність процесів протеолізу контролюється низкою тканинних та плазмових

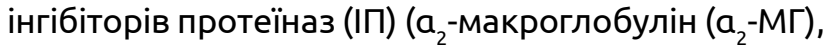
$a_{1}-$-ІП), антитромбін III, тканинний інгібітор матриксної металопротеїнази-1 тощо) [8]. Дисбаланс цієї системи може призвести до переважання проце- сів катаболізму протеїнів, які виконують структурні (компоненти клітинних мембран) та транспортні функції, що $\epsilon$ потужним ушкоджувальним фактором [8].

Таким чином, запалення в дихальних шляхах в подальшому посилюється оксидантним стресом та надлишком протеїназ в легенях, які, на нашу думку, також впливають на розвиток патологічних процесів в шлунку. Аналіз даних літератури свідчить про відсутність дослідження механізмів протеїназо-інгібіторної системи (ПІС) у патогенезі експериментальної пневмонії (ЕП) на тлі виразкової хвороби шлунка (ВХШ). Тому метою нашого дослідження було з'ясування ролі й значення стану протеїназо-інгібіторної системи в легенях у механізмах розвитку ЕП і ВХШ.

Матеріал і методи дослідження. Дослідження проводили на 39 морських свинках-самцях масою 180 - 210 г. Піддослідні тварини були поділені на три групи:

- перша група - контроль (інтактні тварини), 15 тварин;

- друга група - морські свинки з ЕП і ВХШ на 4 добу (12 тварин);

- третя група - морські свинки з ЕП і ВХШ на 8 добу (12 тварин).

Експериментальну пневмонію викликали за методом Шляпникова В.Н., Солодова Т.Л.[9], виразкову хворобу шлунка моделювали за методом Комарова В.И. [10].

Евтаназію тварин здійснювали під ефірним наркозом на 4-ту та 8-у доби формування запального процесу в легенях і виразкової хвороби шлунка.

Визначали стан протеолізу за вмістом: азоальбуміну, азоказеїну, азоколагену в та рівень альфа-2 макроглобулінів (альфа-2 - М) альфа-1 інгібітора протеаз (альфа-1 - IП) за методом К. Н. Веремеенка [11].

Отримані цифрові результати досліджень опрацьовували статистично за методом Стьюдента. 
Огляди літератури, оригінальні дослідження, погляд на проблему

Результати й обговорення. Стан протеїназо-інгібіторної системи організму оцінювали за загальною протеолітичною активністю у легенях - за лізисом азоальбуміну (розпад низькомолекулярних протеїнів), азоказеїну (розпад високомолекулярних протеїнів) і азоколагену (колагеноліз) та інгібіторів протеолізу за вмістом $a_{2}$-макроглобуліну ( $\left.a_{2}-M\right)$ і $a_{1}$-інгібітора протеаз $\left(a_{1}-1 П\right)$ в динаміці розвитку експериментальної пневмонії і виразкової хвороби шлунка.

Отримані результати дослідження показали, що на 4 добу формування ЕП і ВХШ відбувалося зростання вмісту азоальбуміну в легенях на $29,8 \%$ $(P<0,05)$ відносно контролю. Подальше дослідження у легенях лабораторних тварин даного показника (на 8 добу) за умов розвитку експериментальних моделей цих хвороб виявило його підвищення на $38,9 \%(P<0,05)$ проти групи інтактних тварин, що свідчить про стимуляцію процесів протеолізу за умов розвитку експериментальної пневмонії і виразкової хвороби шлунка (рис. 1).

Одним із важливих показників, за яким оцінювали стан протеїназної системи, був азоказеїн, який визначали в легенях в ранній період формування ЕП і ВХШ.

Встановлено, що на 4 добу експерименту відбувалося зростання рівня азоказеїну в легенях на $32,6 \%(P<0,05)$, а згодом, на 8 добу ЕП і ВХШ, було виявлено подальше його підвищення на $46,8 \%$ $(P<0,05)$ проти першої групи тварин (рис. 1$)$.
Аналогічний напрямок змін виявлено під час дослідження лізису азоколагену. Виявлено, що на 4 добу цих експериментальних моделей хвороб відбувалося зростання рівня азоколагену на $31,7 \%(P<0,05)$, а потім, на 8 добу нашого спостереження показано його ще більше підвищення на 49,6\% (P<0,05) відносно групи інтактних морських свинок (рис. 1).

Отже, визначення перерахованих вище маркерів у легенях дало можливість припустити, що експериментальна пневмонія на тлі виразкової хвороби шлунка супроводжується зростанням активності протеолітичних процесів уже на ранніх стадіях формування цих експериментальних моделей хвороб.

Отримані нами результати досліджень позначилися на зміні показників антипротеазного потенціалу за умов розвитку ЕП і ВХШ.

Ми з'ясували, що на 4 добу ЕП і ВХШ відбувалося зниження вмісту альфа-2 - макроглобуліну в легенях на $15,2 \%(P<0,05)$, а згодом, на 8 добу експерименту, було виявлено його подальшу депресію. Рівень його зменшився на $34,6 \%(P<0,05)$ відносно контрольних величин (рис. 2).

Встановлено аналогічний напрям зрушень іншого маркера антипротеазного потенціалу - альфа-1 - інгібітора протеаз (ІП).

На 4 добу ЕП і ВХШ було встановлено його зниження в легенях на 16,8 \% (P<0,05), а далі, на 8 добу експерименту, спостерігалося спадання ІП на 29,5\% $(P<0,05)$ проти першої групи тварин (рис. 2).

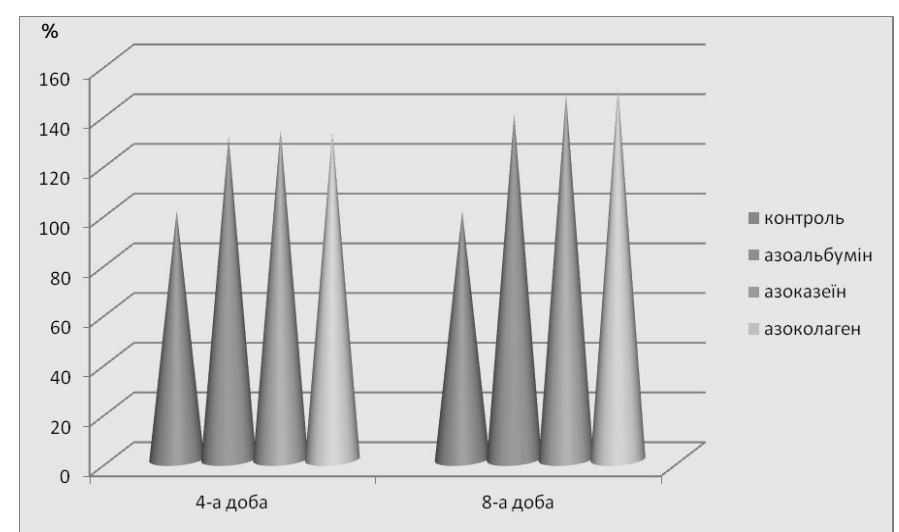

Рис. 1. Стан протеолітичної активності в легенях у ранній період розвитку ЕП і ВХШ (у \% від контролю).

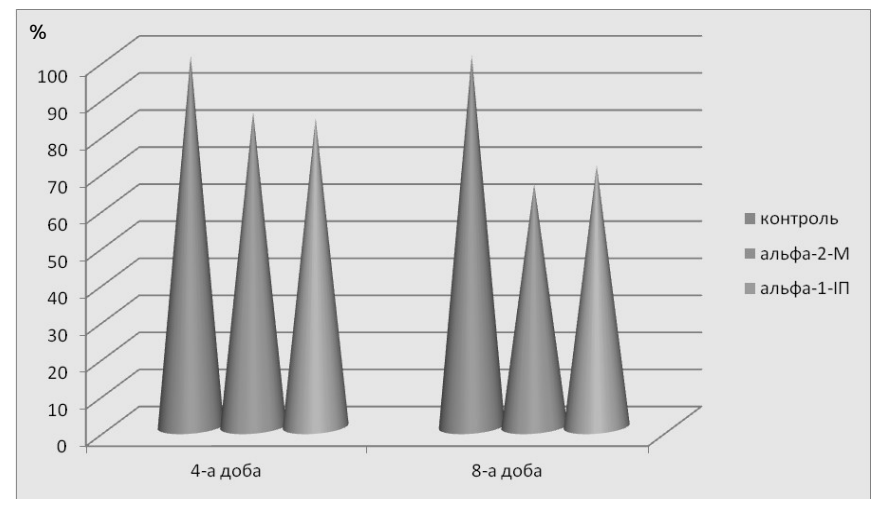

Рис. 2. Стан антипротеазного потенціалу в легенях у ранній період формування ЕП і ВХШ (у \% від контролю). 
Огляди літератури, оригінальні дослідження, погляд на проблему

Висновок. Дослідження показників азоальбуміну, азоказеїну та азоколагену і маркерів інгібіторної системи в легенях показало поступове зростання процесів протеолізу та депресію антипротеазного потенціалу на 4 i 8 доби розвитку ЕП і ВХШ. Це дає підстави стверджувати про пору- шення стану протеїназо-інгібіторної системи у легенях піддослідних тварин, що проявлялося зростанням протеолітичної активності та зниженням інгібіторного потенціалу за умов розвитку експериментальної об'єднаної патології - пневмонії і виразкової хвороби шлунка.

\section{ЛІТЕРАТУРА}

1. Денисюк І. В. Пневмонії: сучасні стандарти діагностики та лікування / І. В. Денисюк, О. В. Денисюк// Український медичний часопис. - 2010. - № 3 (75)V-VI. - С. 75-80.

2. Регеда М. С. Вплив тіотриазоліну на показники перекисного окиснення ліпідів та антиоксидантну систему в легенях у динаміці розвитку експериментальної пневмонії в умовах стресу / М. С. Регеда, С. І. Нестерук // Клінічна фармакологія та фармакологічний нагляд. 2012. - № 1-2. - С. 47-50.

3. Регеда М. С. Пневмонія: монографія / М. С. Регеда, М. М. Регеда, Л. О. Фурдичко. - вид. 6-те доп. та переро6. - Львів, 2012. - С. 162.

4. Сучасні погляди на патогенетичні механізми формування пневмонії / О. А. Ковалишин, М. С. Регеда, Л. А. Любінець, І. В. Челпанова // Практична медицина. - 2013. - T. 19, № 1. - С. 174-180.

5. Ковалишин О. А. Стан протеїназо-інгібіторної системи у легенях у динаміці розвитку експериментальної пневмонії / О. А. Ковалишин // Медична та клінічна хімія. - 2015. - Т. 17, № 1. - С. 66-68.

6. Гуцаленко О. О. Синдром взаємного обтяження: поєднана патологія органів травлення та супутній дуоденогастральний рефлекс / О. О. Гуцаленко // Світ медицини та біології. - 2010. - № 2 (25). - С. 48-50.
7. Гоженко А. И. Особенности поражения слизистой желудка и двенадцатиперстной кишки у больных с хронической обструктивной болезнью легких / А. И. Гоженко, Л. А. Ковалевская, О. В. Кучер, Е.С. Ковалевская// Актуальні проблеми транспортної медицини: навколишнє середовище; професійне здоров'я; патологія. 2013. - № 2(2). - С. 40-44 .

8. Дудка І. В. Інтенсивність оксидативного стресу та протеїназо-інгібіторного дисбалансу у хворих на хронічне обструктивне захворювання легень із супровідною гастроезофагальною рефлексною хворобою та ефективність їх корекції препаратом Гінкго Білоба / І. В. Дудка // Клінічна та експериментальна патологія. 2008. - T. 7, № 3. - С. 40-46.

9. Экспериментальные модели острых пневмоний, вызванных условно-патологическими бактериями и их ассоциацией: метод. указания / сост.: В. Н. Шляпников, Т. л. Солодова [и др.]. - Саратов, 1998. - 30 с.

10. Скляров О. Я. Моделирование процессов гастропротекции и ульцерогенеза слизистой оболочки желудка / О. Я. Скляров, Е. Я. Скляров // Проблемы патологии в эксперименте и клинике. - 1991. - Т. XIII. - С. 72-73.

11. Веремеенко К. Н. Протеолиз в норме и при патологии / К. Н. Веремеенко, О. П. Голобородько, А. И. Кизим. -К. : Здоров'я, 1988. - 200 с.

\section{VALUE OF PROTOLYSIS PROCESSES AND ANTIPROTEASE POTENTIAL IN LUNGS IN THE EARLY PERIOD OF DEVELOPMENT OF THE STOMACH ULCER DISEASE ON THE BACKGROUND OF EXPERIMENTAL PNEUMONIA}

\section{Danylo Halytskyi Lviv National Medical University}

SUMMARY. There was determined in the work that on the $4^{\text {th }}$ day of experimental pneumonia (EP) and stomach ulcer disease (SUD) the increase of level of azocollagen, azocazein, azoalbumin and the decrease of the content ofalpha-2macroglobulins and alpha-1-protease inhibitor in lungsoccured. Later on the $8^{\text {th }}$ day of forming EP and SUD we observed the further increase of proteolisis indices on the background of significant decrease of markers of antiprotease potential in lungs.

KEY WORDS: azocazein, azocolagen, protease inhibitors. 